\title{
Impact of Two Different Anesthetic Techniques on Immune Response and Postoperative Pain for Abdominal Hysterectomy
}

\author{
ENAS MOHAMMED ASHREY, M.D.* and BOSAT ELWANY BOSAT, M.D.** \\ The Departments of Anesthesia, Intensive Care \& Pain Management* and General Surgery**, Faculty of Medicine for Girls, \\ Al-Azhar University, Cairo, Egypt
}

\begin{abstract}
Background: Spinal anesthesia is a famous technique used for lower abdominal surgery, however when it is contraindicated, general anesthesia can be used.

Aim of Study: The aim of this study was to evaluate the impact of anesthetic techniques on immune response and postoperative pain for patients undergoing benign abdominal hysterectomy.

Material and Methods: Forty adult female patients (American physical status (ASA) I-II, 30-60 years) scheduled for abdominal hysterectomy ( $\mathrm{AH}$ ) were allocated to receive either general or spinal anesthesia. Hemodynamic variables were recorded and blood samples were collected for analysis of [Tumor necrosis factor (TNF), Interlucin-6 (IL-6) and Interlucin-10 (IL-10)] levels. Also, Visual Analog Scale (VAS) for postoperative pain with surgeon and patients satisfaction were recorded.
\end{abstract}

Results: Serum analysis of IL-6 and TNF showed significant increase $30 \mathrm{~min}$ after induction of anesthesia and 4 hours postoperatively in Spinal group $(p<0.001)$, while IL-10 showed significant increase 4 hours postoperatively in general group $(p=0.0001)$. VAS was lower in Spinal group than general group ( $\mathrm{p}=0.027)$, with higher patients and surgeons satisfaction scores in spinal group $(p=0.0305) \&(p=0.0803)$ compared with general group.

Conclusion: Our study concluded that spinal anesthesia increase proinflammatory cytokine IL- 6 and TNF during and after surgery, thus stimulating cell immunity and improve postoperative analgesia with better surgeon and patients satisfaction than general anesthesia.

Key Words: Abdominal hysterectomy - General anesthesia Spinal anesthesia - Visual analog scale.

\section{Introduction}

HYSTERECTOMY is one of the most common surgical procedures performed for women throughout the world, next only to caesarean section. Abdominal hysterectomy is considered the most

Correspondence to: Dr. Enas Mohammed Ashrey, E-Mail: drenasenas@yahoo.com. common approach, despite the fact that vaginal hysterectomy or laparoscopic hysterectomy should be the preferred route $[\mathbf{1 , 2 , 3 ]}$. This can be explained by personal preference or may be due to a lack of training and experience [4]. It can be performed for benign and malignant conditions; approximately $90 \%$ of hysterectomies are performed for benign conditions such as fibroids causing abnormal uterine bleeding [5].

Surgical tissue injury is correlated with impaired immune responses, which could be associated with dysregulated proinflammatory cytokines, or with the inhibition of cellular responses. Also combination between anesthesia and surgical stress may have an impact on the inflammatory responses, which are vital for preserving the postoperative homeostatic state [6]. Various anesthetics have been supposed to harm many of the immune system functions both directly by altering the performance of immune-competent cells and indirectly by adjusting stress response [7]. Also may hinder stress response mainly, cytokine activation during and after surgery and there is not clear evidence of the immunomodulatory effect of anesthesia on cytokine production. Anesthetic methods also may influence adrenergic activity [8].

The proposed study was designed to assess the effect of two anesthetic techniques on pro-[TNF, IL-6] and anti-inflammatory [IL-10] cytokines levels and postoperative analgesia with surgeon and patients satisfaction in patients undergoing benign abdominal hysterectomy.

\section{Patients and Methods}

A- Study design: This prospective study was carried out on 40 adult female patients enrolled for abdominal hysterectomy under either general or spinal anesthesia in Al-Zahraa University Hos- 
pital during the period from Octobar 2017 to December 2018.

$B$ - Inclusion criteria: Forty female patients aged between 30-60 years of (ASA) I, II scheduled for benign abdominal hysterectomy (uterine fibroids, heavy menstrual bleeding or metrorrhagia of adenomyosis) were included in this study, under either general or spinal anesthesia.

$C$ - Exclusion criteria: Patients with advanced cardiac, renal or endocrine disease $\&$ any systemic illness known to affect the inflammatory process such as rheumatoid arthritis. Also patients under steroid treatment within 3 months or immunosuppressive drugs or malignant disease were excluded from the study.

$D$ - Ethical consideration: Informed consent was obtained from all patients after approval of the local ethical committee.

E- Randomization: Patients were randomly classified into two groups (20) patients in each, by using a computer-generated number lists and by using sealed opaque envelopes, Fig. (1).

- Group (I) general anesthesia group (GA: $n=20)$, - Group (II) spinal anesthesia group (SA: $n=20$ ).

\section{Both groups were subjected to the following:}

The patient is transported to the operating room, a- An intravenous cannula of (22-18G) was placed and preloaded by $500 \mathrm{ml}$ of ringer lactate solution over $15 \mathrm{~min}$ followed by an infusion of 6$10 \mathrm{ml} / \mathrm{kg} / \mathrm{h}$, without any premedication.

b- All patients were monitored for heart rate (HR), oxygen saturation $(\mathrm{SpO} 2)$, and noninvasive mean arterial blood pressure (MABP).

In group (I): General anesthesia was induced with fentanyl 1 / $/$ lidocaine $1 \mathrm{mg} / \mathrm{kg}$ and thiopental $3-5 \mathrm{mg} / \mathrm{kg}$. Cisatracurium $0.15 \mathrm{mg} / \mathrm{kg}$ and isoflurane in oxygen with $\mathrm{FiO} 2,0.6$ ( $3 \mathrm{l} / \mathrm{min})$ were administered to maintain the adequate depth of anesthesia. After intubation, maintenance by isoflurane MAC (0.8-1.2\%), incremental doses of fentanyl and cisatracurium $(0.03 \mathrm{mg} / \mathrm{kg})$ were given. After completion of surgery, neuromuscular blockade was antagonized by $0.01 \mathrm{mg} / \mathrm{kg}$ of atropine + $0.05 \mathrm{mg} / \mathrm{kg}$ of neostigmine.

In group (II): Spinal anesthesia was induced after sterile preparation and drape in the sitting position with 25 gauge spinal needle introduced into the subarachnoid space at lumber level (L3L4) and after careful aspiration of cerebrospinal fluid, intrathecal administration of (12.5-15mg) of levobupivacaine $+25 \mu \mathrm{g}$ of fentanyl was injected.
At the end of surgery patients were transferred to the recovery room for continous assessment of vital parameters, and all patients in the two groups routinely received paracetamol $1 \mathrm{~g} / 8 \mathrm{~h}$ IV. Intramuscular non steroidal anti-inflammatory drugs, ketorolac tromethamine (Adolor) $30 \mathrm{mg} / 2 \mathrm{ml}$ was given when VAS more than 3. All surgeries were carried out by the same surgeon.

Surgical technique: Abdominal hysterectomy involves surgical removal of the uterus through an incision in the lower abdomen (midline or a Pfannenstiel); it is either total hysterectomy involves removing the entire uterus including the cervix or Subtotal hysterectomy including removing the body of the uterus while the lower part of the cervix is preserved, depending on the expected surgical difficulty and the size of the uterus.

\section{Outcome of the study:}

The primary outcome of this study was to evaluate the effect of two different anesthetic techniques on serum level of IL-6, TNF and IL-10. The secondary outcome was to assess pain intensity and postoperative analgesic consumption with surgeon and patients satisfaction in patients undergoing benign abdominal hysterectomy.

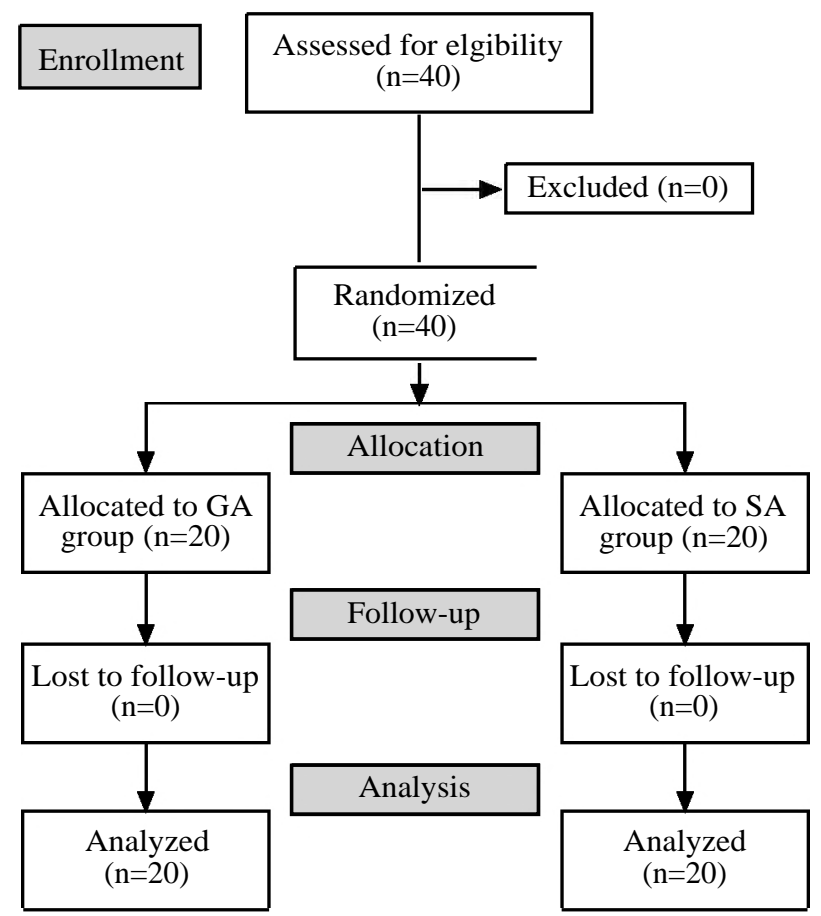

Fig. (1): Consort flow diagram of the two groups.

\section{Parameters of assessment:}

1- Demographic and operative data:Including, age, BMI, ASA classification, HR, MBP, SPO 2 and duration of operation were recorded. Baseline readings were measured and recorded every 
$10 \mathrm{~min}$ intraoperatively, and postoperatively until complete recovery.

2- Biochemical analysis (measurement of IL-6, $T N F$ and $I L-10)$ : Three samples of $4 \mathrm{ml}$ venous blood (Preinduction, 30 minute after induction of anesthesia and $4 \mathrm{~h}$ postoperative) were drawn in plain tubes under sterile conditions from each patient. Serum was rapidly centrifuged and frozen at -70 linked immunosorbent assay (ELI$\mathrm{SA})$ technique.

3- The VAS scale for postoperative pain: Consists of $10 \mathrm{~cm}$ horizontal line ranging from 0 (no pain) to 10 (intolerable pain). Patients were asked to mark the line vertically at a point which matched their pain. VAS score was recorded by attending resident immediately after operation both at rest and on movement subsequently at $2 \mathrm{~h}, 4 \mathrm{~h}, 6 \mathrm{~h}, 12 \mathrm{~h}, 24 \mathrm{~h}$ after the recovery.

4- Postoperative criteria for: Patients rescue analgesia and total ketorolac consumption during the first postoperative $24 \mathrm{~h}$ were recorded. $\mathrm{Pa}-$ tients and surgeon satisfaction: Were asked and assessed. On a five-point likert scale is a rating scale that can help you determine to what extent participants agree or disagree with a current statement where, 5 ; indicated very satisfied, 4; satisfied, 3; neutral, 2; unsatisfied and 1; very unsatisfied. Postoperative nausea and vomiting [PONV]; was assessed as number of attacks of nausea or vomiting in the first $24 \mathrm{~h}$ after surgery, where metoclopramide $10 \mathrm{mg}$ IV was given for every attack of nausea or vomiting.

Sample size: The sample size was calculated by using MedCalc version 12.3.0.0 program which is a statistical calculator based on $95 \%$ confidence interval, showed that at least 40 patients ( 20 per group) was determined to be sufficient to detect a difference in cytokine level and VAS between the groups at the $5 \%$ a significant level $\alpha$ (alpha) with approximately $80 \%$ power.

Statistical analysis: Statistical analysis was done by using Statistical package for social sciences (SPSS version 20 Inc., Chicago, Illinois, USA). Data were expressed as mean \pm standard deviation for quantitative data, number and percentage in qualitative one. $t$-test, paired T-test and chi-squared test were used as appropriate ANOVA for the repeated measures. A $p$-value of $<0.05$ was considered statistically significant.

\section{Results}

There were no statistically significant differences between the two studied groups as regard age, BMI, ASA and duration of operation $(p>0.05)$.
Also there were no significant differences between the two studied groups as regards heart rate, mean blood pressure at all measured times $(p>0.05)$ Table (1).

Table (1): Demographic and operative data in both groups.

\begin{tabular}{llll}
\hline $\begin{array}{l}\text { Demographic } \\
\text { data }\end{array}$ & $\begin{array}{c}\text { Group I (GA) } \\
(\mathrm{N}=20)\end{array}$ & $\begin{array}{c}\text { Group II (SA) } \\
(\mathrm{N}=20)\end{array}$ & $\begin{array}{c}p \text { - } \\
\text { value }\end{array}$ \\
\hline Age in years & $37.44 \pm 12.55$ & $40.14 \pm 11.95$ & 0.490 \\
BMI (kg/m $\left.{ }^{2}\right)$ & $26.8 \pm 4.7$ & $25.9 \pm 3.4$ & 0.492 \\
ASA I, II (n) & $17 / 3$ & $16 / 4$ & 0.523 \\
HR (bpm) & $83.13 \pm 5.07$ & $82.93 \pm 5.18$ & 0.902 \\
MBP (mmHg) & $74.33 \pm 4.72$ & $73.80 \pm 3.86$ & 0.699 \\
Duration of & $104.0 \pm 13.8$ & $101.7 \pm 14.9$ & 1.000 \\
$\quad$ operation (min) & & & \\
\hline
\end{tabular}

Data are expressed as mean $\pm \mathrm{SD}$, numbers. ${ }^{*} p>0.05$ : NS.

\section{Biochemical analysis:}

There was no statistically significant difference between both groups in the IL-6, TNF, IL-10, before induction of anesthesia $(p>0.05)$ but;

- IL-6: Showed highly significant increase in the IL-6 $(p<0.000), 30 \mathrm{~min}$ after induction of anesthesia $(0.55 \pm 0.09$ in GA vs $1.124 \pm 0.19$ in SA) and 4 hours postoperative $(0.12 \pm 0.05$ in GA vs $0.98 \pm 0.02$ in $\mathrm{SA}$ ) in spinal group than general group.

- TNF: Showed highly significant difference between both groups $30 \mathrm{~min}$ after induction of anesthesia $(0.12 \pm 0.01$ in GA vs $0.24 \pm 0.09$ in SA) and 4 hours postoperatively $(0.25 \pm 0.01$ in GA vs $0.44 \pm 0.02$ in $\mathrm{SA}$ ) in spinal group than general group $(p<0.000)$.

- IL-10: Only 4 hours postoperatively, IL- 10 levels was $(1.04 \pm 0.52$ in GA vs $0.15 \pm 0.01$ in SA) which is highly significant $(p<0.000)$, Table $(2)$.

Table (2): Assessment of IL6 (pg/ml), TNF (pg/ml), IL10 $(\mathrm{pg} / \mathrm{ml})$ between the groups.

\begin{tabular}{|c|c|c|c|}
\hline Variables & $\begin{array}{l}\text { Group I (GA) } \\
(\mathrm{N}=20)\end{array}$ & $\begin{array}{c}\text { Group II (SA) } \\
\qquad(\mathrm{N}=20)\end{array}$ & $\begin{array}{c}p- \\
\text { value }\end{array}$ \\
\hline \multicolumn{4}{|l|}{ IL6 $(\mathrm{pg} / \mathrm{ml}):$} \\
\hline Pre induction & $0.19 \pm 0.09$ & $0.14 \pm 0.07$ & 0.0572 \\
\hline $30 \mathrm{~min}$ after induction & $0.55 \pm 0.09$ & $1.124 \pm 0.19$ & $0.000 *$ \\
\hline 4h post-operative & $0.12 \pm 0.05$ & $0.98 \pm 0.02$ & $0.000 *$ \\
\hline \multicolumn{4}{|l|}{$T N F(p g / m l):$} \\
\hline Pre induction & $0.12 \pm 0.05$ & $0.14 \pm 0.02$ & 0.105 \\
\hline $30 \mathrm{~min}$ after induction & $0.12 \pm 0.01$ & $0.24 \pm 0.09$ & $0.000 *$ \\
\hline $4 \mathrm{~h}$ post-operative & $0.25 \pm 0.01$ & $0.44 \pm 0.02$ & $0.000 *$ \\
\hline \multicolumn{4}{|l|}{ ILIO $(\mathrm{pg} / \mathrm{ml})$ : } \\
\hline Pre induction & $0.15 \pm 0.07$ & $0.14 \pm 0.09$ & 0.6971 \\
\hline $30 \mathrm{~min}$ after induction & $0.06 \pm 0.02$ & $0.05 \pm 0.01$ & 0.0527 \\
\hline 4h post-operative & $1.04 \pm 0.52$ & $0.15 \pm 0.01$ & $0.000 *$ \\
\hline
\end{tabular}


Postoperative visual analog scale: Recorded after operation both at rest and on movement subsequently at $2 \mathrm{~h}, 4 \mathrm{~h}, 6 \mathrm{~h}, 12 \mathrm{~h}, 24 \mathrm{~h}$ after the recovery and showed significantly lower in spinal group than general group $(p<0.005)$, Fig. (2).

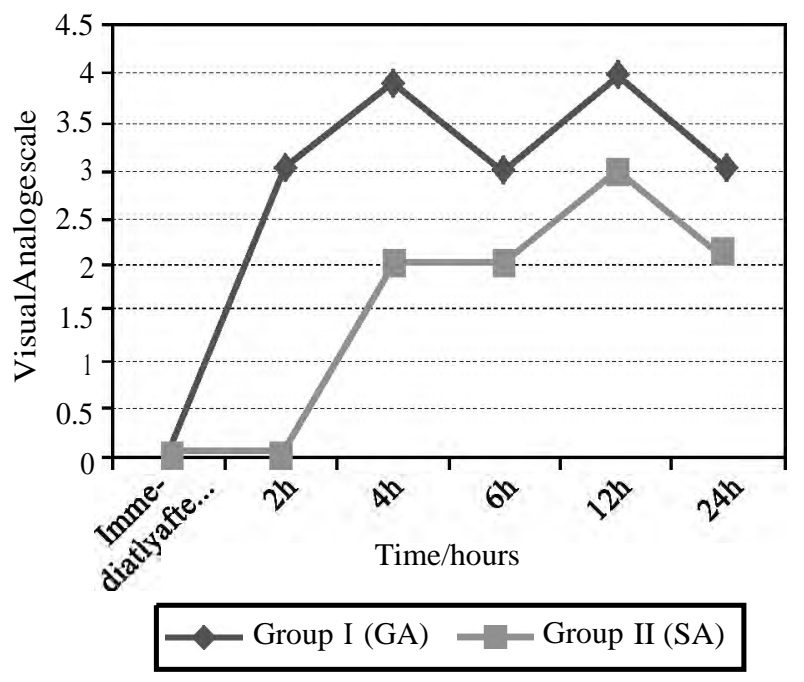

Fig. (2): Postoperative visual analog scales (VAS).

Postoperative criteria: Postoperative rescue analgesic consumption was lower in patients in SA group $24 \mathrm{~h}$ postoperative ( $75 \mathrm{mg}$ ketorolac) in comparison with (150mg ketorolac) for patients in GA group ( $p=0.0271$ ) Patients in SA group reported higher overall satisfaction scores than patients in GA group $(p=0.0305)$. Also all surgeons' satisfaction score was highly satisfied for SA group compared with GA group ( $p=0.0803)$, incidence of adverse effects for postoperative nausea and vomiting showed no significant difference between the two groups ( $p=0.6369$ ), Table (3).

Table (3): Postoperative criteria in both groups.

\begin{tabular}{|c|c|c|c|}
\hline Variables & $\begin{array}{l}\text { Group I } \\
(\mathrm{GA}) \\
(\mathrm{N}=20)\end{array}$ & $\begin{array}{l}\text { Group II } \\
\text { (SA) } \\
(\mathrm{N}=20)\end{array}$ & $\begin{array}{c}p- \\
\text { value }\end{array}$ \\
\hline Patients rescue analgesia & $15(75 \%)$ & $8 \quad(40 \%)$ & 0.0271 \\
\hline $\begin{array}{l}\text { Total ketorolac consumption } \\
\text { (dose/mg) }\end{array}$ & $150 \mathrm{mg}$ & $75 \mathrm{mg}$ & \\
\hline $\begin{array}{l}\text { Patients satisfaction: } \\
\text { Satisfied } \\
\text { Unsatisfied }\end{array}$ & $\begin{array}{l}12(60 \%) \\
8(40 \%)\end{array}$ & $\begin{array}{l}18(90 \%) \\
2(10 \%)\end{array}$ & 0.0305 \\
\hline $\begin{array}{l}\text { Surgeon satisfaction: } \\
\text { Satisfied } \\
\text { Unsatisfied }\end{array}$ & $\begin{array}{l}15(75 \%) \\
5(25 \%)\end{array}$ & $\begin{array}{l}19(95 \%) \\
1 \quad(5 \%)\end{array}$ & 0.0803 \\
\hline $\begin{array}{l}\text { Postoperative nausea and } \\
\text { vomiting }\end{array}$ & $3(15 \%)$ & $2(10 \%)$ & 0.6369 \\
\hline
\end{tabular}

Data are expressed as number and percentage. $p<0.05 *$ : Significant.

\section{Discussion}

Excessive stimulation of the inflammatory and haemostatic systems per operatively manifesting as increased tendency to infections, plays a role in the development of postoperative disorders and pain, so the inflammatory response is considered as an important determinant of outcome after major surgery [9]. Cytokines are produced as an early response to tissue injury from activated leucocytes, fibroblasts and endothelial cells and considered as a group of low-molecular-weight proteins, that is include the interleukins and interferons and have a major local effect in mediating immunity and inflammation in response to tissue injury. Also it initiate some of the systemic changes, after major surgery the main cytokines released are IL-I, TNF and IL- 6 from activated macrophages and monocytes at the damaged tissues, and IL-6 is the main cytokine responsible for inducing the systemic changes that is known as the acute phase response [10] . IL-10 suppresses activation of macrophages and inhibiting their ability to secrete cytokines and to act as accessory cells for stimulation of $\mathrm{T}$ cell and NK cell function. So it described as a cytokine synthesis inhibitory factor. It down-regulates cellmediated responses which suppressing the production of PGE2 and proinflammatory cytokines, IL2 and IFN, it also enhances release of soluble TNF receptor $[11,12]$

Our study assess the effect of two different anesthetic technique (general or spinal) on perioperative immune response of cytokine level (IL6 , TNF, IL-10) in patients undergoing benign abdominal hysterectomy.

Regarding hemodynamic data, there was no statistically significant difference between both groups all through times of study, this can be explained by preloaded with a good volume of crystalloid solution, and prophylactic administration of IV ephedrine to reduce hypotension. Co incised with our study Amin and Salah, [13] studied the effect of general or spinal anesthesia on pro- and anti-inflammatory Intracellular cytokines and found no significant differences in hemodynamic changes between the two groups.

Our study recorded that there was no statistically significant difference between both groups in the IL-6, TNF, IL-10 pre operatively, but 30 minute after induction and 4 hours postoperatively the levels of IL-6, TNF were significantly higher in (SA) group than (GA) group $(p<0.001)$, Which indicate that spinal anesthesia increase the production of proinflammatory cytokines. Anti-inflam- 
matory IL-10 also showed significant increase in the (GA) group 4 hours postoperatively than (SA) group and this describe that the anesthetic technique affects the release of cytokines.

Yangjie Dang et al., [14] showed that compared to general anesthesia, regional anesthesia reduce the inhibition of immune function. Also Alan David Kaye et al., [15] advised to use regional analgesia than general anesthesia to avoid immune suppression, as the immunosuppressive effects of regional anesthesia may be less than the immunosuppressive effects of general anesthesia.

Also, these finding are in line with the result of T. Kawasaki et al., [16], who demonstrated increase serum level of IL-10, $2 \mathrm{~h}$ after the beginning of surgery and peaked at end of surgery in patients receiving GA and showed no significant differences between GA and GA \& epidural group and this was related to the mechanisms of suppressing immune functions, such as phagocytic activity, lipopolysaccaride, hyporesponsiveness, and monocyte HLA-DR expression. In contrast to our study Maryam et al., [17] who studied 40 patients with preeclampsia undergoing cesarean section under either general or regional anesthesia, where they had lower levels of IL-6 in regional group and increased level of IL-6 and IL-10 after surgery in general group $(p<0.05)$, with no significant effect on TNF.

VAS and analgesic requirement in our research, was lower in SA group than GA group, this coincides with Woldin et al., [18] who reported those women that undergoing for hysterectomy under SA with intrathecal morphine had significantly less postoperative pain in the surgical area compared with GA, this indicates that SA provides a superior and prolonged postoperative analgesia. Also, Dahl et al., and Borgdorff et al., [19,20] showed that intrathecal opioids prevent hormonal stress response associated with surgery, leads to less pain and reduce postoperative analgesia. Attari et al., [21] explain that, there were two different mechanisms for the decrease in postoperative analgesia used in the SA, first mechanism is the preemptive effect of SA that decreases the pain scores by preventing afferent nociceptive sensitization pathway and lower analgesic requirement after operation, the second mechanism was probably due to some residual sensory blockade in SA group.

Additionally, our study showed that there were higher patients, and surgeon satisfaction in (SA) group than (GA) group with no significant adverse effect between both groups. Similar to our result
Fischer [22] founded that opioid-sparing effects of spinal anesthesia, were associated with a better patient, and surgeon satisfaction after surgery. Catro et al., [23] confirmed that SA provides better patients satisfaction and quality of recovery than GA for patients undergoing abdominal hysterectomy. Ellakany [24] provided that patients received thoracic spinal anesthesia had better satisfaction than patients received general anesthesia with no significant difference between both groups in PONV, but surgeon satisfaction was higher for GA group than thoracic SA group. Also, studies done by (Acikel et al., and Mostafa et al., [25,26] provide higher patients satisfaction with spinal anesthesia.

\section{Conclusion:}

Our study concluded that spinal anesthesia increase proinflammatory cytokine IL-6 and TNF during and after surgery, thus stimulating cell immunity and improve postoperative analgesia with better surgeon and patients satisfaction than general anesthesia.

Limitation to our study: We recommend to study on large number of patients and measure cytokine level at $(12,24 \mathrm{hrs})$ after surgery and measure other types of cytokines if possible.

\section{References}

1- CLAYTON R.D.: Hysterectomy. Best Practice \& Research Clinical Obstetrics \& Gynaecology, 20 (1): 73-87, 2006.

2- AAGL: Advancing Minimally Invasive Gynecology Worldwide. AAGL position statement: Route of hysterectomy to treat benign uterine disease. J. Minim Invasive Gynecol., 18 (1): 1-3, 2011

3- DEEKSHA PANDEY, KRITI SEHGAL, AASHISH SAXENA, SHRIPAD HEBBAR, JAYARAM NAMBIAR and RAJESHWARI G. BHAT: An audit of indications, complications, and justification of hysterectomies at a teaching hospital in India. International Journal of Reproductive Medicine, V 2014, pp. 1-6, 2014.

4- McCRACKEN G. and LEFEBVRE G.G.: Vaginal Hysterectomy. Dispelling the Myths. J. Obstet. Gynecol. Can., 29: 424-428, 2007.

5- JOHANNA W.M. AARTS, THEODOOR E. NIEBOER, NEIL JOHNSON, EMMA TAVENDER, RAY GARRY, BEN WILLEM J. MOL and KIRSTEN B. KLUIVERS: Surgical approach to hysterectomy for benign gynaecological disease (Review). (Cochrane Library. Cochrane Database of Systematic Reviews), pp. 1-214, 2015.

6- SALO M.: Effects of anaesthesia and surgery on the immune response. Acta. Anaesthesiol., 36: 201-20, 1992.

7- SCHNEEMILCH C.E., BANK U.: Release of pro-and anti-inflammatory cytokines during different anesthesia procedures. Anaesthesiol. Reanim., 26: 4-10, 2001.

8- ADINA HADADE: The Impact of Anesthesia and Surgery on Plasma Cytokine Production. Biotechnology, Molecular Biology and Nanomedicine, V2 (1): pp. 26-29, 2014. 


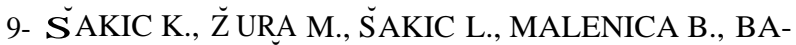
GATIN D. and S TURM D.: Anaestethic technique and cytokine response, PERIODICUM BIOLOGORUM: An international journal of the Societas Scientarium Naturalium, V. 113 (2): 151-156, 2011.

10- DESBOROUGH J.P.: The stress response to trauma and surgery. Br. J. Anaesth., 85: 109-17, 2000.

11- WILLEMS F., MARCHANT A., DELVILLE J.P., GERARD C., DELVAUX A., VELU T., de BOER M. and GOLDMAN M.: Interleukin-10 inhibits B7 and intercellular adhesion molecule- 1 expression on human monocytes. European Journal of Immunology, 24: 1007-1009, 1994.

12- SHEERAN P. and HALL G.M.: Cytokines in anaesthesia. Br. J. Anaesth., 78: 201-19, 1997.

13- AMIN O.A.I. and SALAH H.E: The effect of general or spinal anaesthesia on pro- and anti-inflammatory intracellular cytokines in patients undergoing appendecectomy using flowcytometric method. Egypt J. Anaesth., 27 (2): 121-125, 2011.

14- YANGJIE DANG, XINGXING SHI, WILLIAM XU and MINGZHANG ZUO: The Effect of Anesthesia on the Immune System in Colorectal Cancer Patients. Review Article Canadian Journal of Gastroenterology and Hepatology, V. (2018): pp. 1-8, 2018.

15- ALAN DAVID KAYE, NAYAN PATEL, FRANKLIN RIVERA BUENO, BRAD HYMEL, NALINI VADIVELU, GOPAL KODUMUDI B.S. and RICHARD D. URMAN: Effect of Opiates, Anesthetic Techniques, and Other Perioperative Factors on Surgical Cancer Patients. The Ochsner Journal, V. (14): pp. 216-228, 2014.

16- T. KAWASAKI, M. OGATA, C. KAWASAKI, K. OKAMOTO and T. SATA: Effects of epidural anaesthesia on surgical stress induce immuno suppression during upper abdominal surgery. BJA, 98 (2): 196-203, 2007.

17- MARYAM VOSOUGHIAN, MASTANEH DAHITALEGHANI, MOHAMMADREZA MOSHARI, SAMIRA RAJAEI, SHIMA RAJABI and FARINAZ TAHERI: Effect of Spinal and General Anesthesia on Serum Cytokine Levels Following Cesarean Section in Preeclampsia. J. Cell Mol. Anesth., 3 (3): 89-97, 2018.

18-WOLDIN N.B., NILSON L., ARESTEDT K., KJOLHEDE P.: Mode of anesthesia and postoperative symptoms fol- lowing abdominal hysterectomy in a fast-track setting. Acta. Obstet. Gynecol. Scand, 90 (4): 369-79, 2011.

19- DAHL J.B., JEPPESEN I.S., JØRGENSEN H., WETTERSLEV J. and MØINICHE S.: Intraoperative and postoperative analgesic efficacy and adverse effects of intrathecal opioids in patients undergoing cesarean section with spinal anesthesia: A qualitative and quantitative systematic review of randomised controlled trials. Anesthesiology, 91: 1919-27, 1999.

20- BORGDORFF P.J., IONESCU T.I., HOUWELING P.L. and KNAPE J.T.: Large-dose intrathecal sufentanil prevents the hormonal stress response during major abdominal surgery: Acomparison with intravenous sufentanil in a prospective randomized trial. Anesth. Analg., 99: 111420, 2004.

21- ATTARI M.A., MIRHOSSEINI S.A., HONARMAND A and SAFAVI M.R.: Spinal anesthesia versus general anesthesia for elective lumbar spine surgery: A randomized clinical trial. J. Res. Med. Sci., 16 (4): 524-529, 2011.

22- FISCHER B.: Benefits, risks, and best practice in regional anesthesia: Do we have the evidence we need? Reg. Anesth. Pain Med., 35: 545-8, 2010.

23- CATRO-ALVES L.J., De AZEVEDO V.L., De FREITAS BRAGA T.F., GONCALVES A.C. and De OLIVEIRA G.S. Jr.: The effect of neuraxial versus general anesthesia techniques on postoperative quality of recovery and analgesia after abdominal hysterectomy: A prospective, randomized, controlled trial. Anesth. Analg., 113 (6): 1480-6, 2011

24- ELLAKANY M.: Comparative study between general and thoracic spinal anesthesia for laparoscopic cholecystectomy. Egyptian Journal of Anaesthesia, 29: (4): 375$381,2013$.

25- AÇ1KEL A., ÖZTÜRK T., GÖKER A., HAYRAN G.G. and KELES G.T.: Comparison of Patient Satisfaction Between General and Spinal Anaesthesia in Emergency Caesarean Deliveries. Turk J. Anaesthesiol. Reanim., 45: 41-6, 2017.

26- MOSTAFA SADEGHI, REIHANEH BAYAT, OMID AZIMARAGHI and ALIREZA SALIMINIA: Maternal Satisfaction of Spinal Anesthesia for Elective Cesarean Section in an Academic Hospital. Ann. Anesth. Crit. Care, 2 (2): pp. 1-6, 2017. 


\section{تأثير تقنيتين مختلفين من التخدير على الاستجابة المناعية وآلام ما بعد الجراحة الاستئصال الرحمى الاسيتابح}

أن التخدير النصفى من التقنيات التخديرية الشهيرة التى تستخدم لجراحات البطن السفلية، ولكن عندما يكن هناك مانع يتم استخدام التخدير الكلى.

الهدف من هذه الدراسـة: هو تقييم تأثير تقنيتين مختلفتين من التخدير على الاستجابة المناعية وآلام ما بعد الجراحة للمرضى الذين

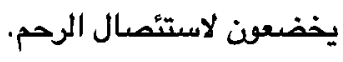

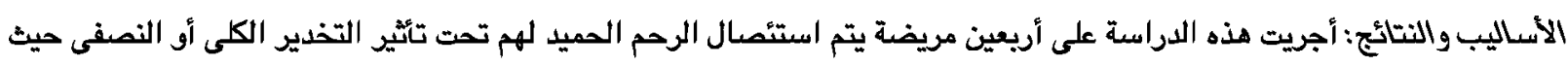

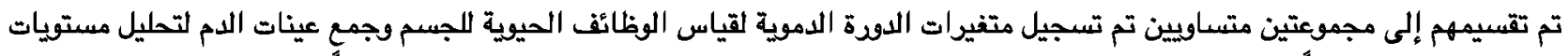

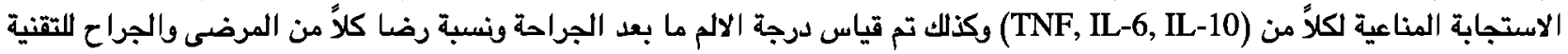
التخديرية المستخدمة.

وقد أسفرت هذه الدراسة إلى أن التخدير النصفى يزيد من الاستجابة المناعية الجسم IL-6, TNF أثناء وبعد الجراحة، مما يحفز مناعة

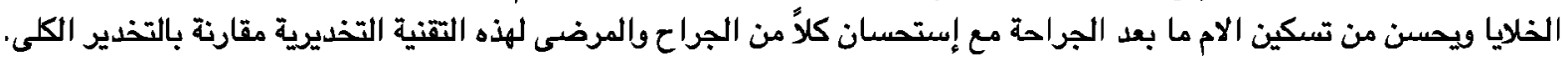

